\title{
Effects of temperature and volume of water on the growth and development of tadpoles of Pleurodema diplolister and Rhinella granulosa (Amphibia: Anura)
}

\author{
Thely A. Maciel ${ }^{1} \&$ Flora A. Juncá ${ }^{2}$ \\ 1 E-mail: thelyam@yahoo.com.br \\ ${ }^{2}$ Departamento de Ciências Biológicas, Universidade Estadual de Feira de Santana. Campus Universitário, 44031-460 Feira \\ de Santana, Bahia. E-mail: florajunca@yahoo.com.br
}

\begin{abstract}
The capacity of tadpoles to reduce their metamorphosis time and body size in response to fluctuations in environmental variables of temporary ponds has been recorded in field and laboratory studies. The main alterations in this habitat are related to the decrease of the water level and increase in temperature. However, few studies tried to dissociate the effect of these two variables. The aim of the present study was to analyze simultaneously the effects of water volume reduction and temperature on the development and growth in tadpoles of Pleurodema diplolister (Peters, 1870) and Rhinella granulosa (Spix, 1824) - species that use temporary ponds for reproduction. The tadpoles of these two species were subject to four treatments: (1) constant volume of water of $2000 \mathrm{ml}$ and constant temperature of $26^{\circ} \mathrm{C}$; (2) gradually decreasing water volume from $2000 \mathrm{ml}$ to $200 \mathrm{ml}$ or $150 \mathrm{ml}$ and constant temperature of $26^{\circ} \mathrm{C}$; (3) Constant water volume as in (1) and constant temperature of $30^{\circ} \mathrm{C}$ or $33^{\circ} \mathrm{C}$ and (4) Decreasing water volume (as above) and constant temperature as in the treatment (3). There was no interaction between both tested variables on the growth and development of tadpoles of both species. Tadpoles of $P$. diplolister and $R$. granulosa responded to high temperature by decreasing development time. Tadpoles responded to decreasing volume of water by metamorphosing into smaller size. Tadpoles of $P$. diplolister maintained at $30^{\circ} \mathrm{C}$ showed growth reduction. Tadpoles of $R$. granulosa increased their body size when subject to the treatment at $30^{\circ} \mathrm{C}$.
\end{abstract}

KEY WORDS. Bufonidae; Leiuperidae; temporary ponds.

The plasticity in development time and body size of amphibian larvae living on temporary environments has been recorded for some species through field and laboratory experiments. Amphibian larvae developing in temporary environments have a tendency to reduce development time, migrating sooner to terrestrial environments and thus avoiding the constant changes in the biotic and in the abiotic factors that are characteristic of temporary bodies of water (DuelLman \& TRueb 1986). Among these changes, the most remarkable one is water loss, which leads to several consequences, including increased population density, reduction of the amount of food, and an increase in water temperature (Wilbur \& Collins 1973, Wilbur 1990). However, tadpoles of Spea hammondii (Baird, 1859) (Denver et al. 1998) and Rana temporaria Linnaeus, 1758 (MerILA et al. 2000) reared separately under desiccation conditions were able to accelerate metamorphosis and reduce body size, showing that such response may be independent of density. According Denver et al. (1998), the water restriction for the tadpoles of $S$. hammondii decrease space for locomotion, inhibiting the foraging behavior and causing a reduction in their body size and has been pointed as the triggering factor for the reduction of the time of develop- ment and consequent reduction of the body size of the tadpoles (Semlistsch \& Wilbur 1988, Crump 1989, Newman 1989, Tejedo \& Reques 1994, Denver 1997, Denver et al. 1998, Laurila \& Kujasalo 1999, Merila et al. 2000).

The temperature, on the other hand, is strongly associated to the amount of water in temporary environments, since the water loss may cause an elevation in the mean temperature and an increase in the daily thermal variation of bodies of water (Wilbur 1990). Some studies suggested the possible effect of temperature on the duration of the larval period of anurans in temporary environments (Crump 1989, Newman 1989), whereas LomAn (2002) detected a significant effect of temperature on the time of development of Rana arvalis Nilsson, 1842 and Rana temporaria and indicated this variable as the most important to determine the time of development of tadpoles of those species. However, at least two laboratory studies sought to dissociate the effect of the water reduction and the temperature on the larval phase of anuran amphibians and found a more rapid larval development only in response to the water restriction (Laurila \& Kujasalo 1999, Merila et al. 2000). Thus, it seems that the effect of temperature on the development of 
the tadpoles in temporary environments is not well understood, although BRADY \& Griffiths (2000) have suggested that development and growth are influenced by different environmental factors such that temperature determines the development of the larvae, while the change in the water level determines the body size.

Tadpoles of the leiuperid Pleurodema diplolister (Peters, 1870) and the bufonid Rhinella granulosa (Spix 1824) develop in temporary environments and may, therefore, be valuable organisms in studies seeking to understand how the amount of water and temperature may influence the larval period of the species of anuran amphibians. Both species are distributed predominantly at northeastern Brazil (Frost 2008, Narvaes \& RoDRIGUEs 2009) and are found in areas of Caatinga and in open formations of Atlantic Rainforest (CARdoso \& ARZAbe 1993, personal obs.) The aim of this study was analyze the effects of temperature and water level on the time of development and body size of tadpoles of $P$. diplolister and $R$. granulosa.

\section{MATERIAL AND METHODS}

A $2 \times 2$ factorial design was used to assess the effect of water volume and temperature on the development and growth of larvae of $P$. diplolister and $R$. granulosa. The factors water (with two levels, constant and reduced) and temperature $\left(26^{\circ} \mathrm{C}\right.$ and $30^{\circ}$ for $P$. diplolister and $26^{\circ} \mathrm{C}$ and $33^{\circ} \mathrm{C}$ for $R$. granulosa) were combined so that the four groups formed (treatments) representing all the possible combinations among factor levels.

The experiments with $P$. diplolister and $R$. granulosa were carried in different periods. The egg masses of $P$. diplolister $(n=7)$ were collected at the campus of the Universidade Estadual de Feira de Santana (EUFS), municipality of Feira de Santana, state of Bahia, on February $17^{\text {th }}$ and $18^{\text {th }}, 2007$ in temporary water ponds, exposed directly to the sunlight and at a depth not exceeding $4 \mathrm{~cm}$. Egg masses of $R$. granulosa $(\mathrm{n}=2)$ were collected in temporary ponds of UEFS on March $1^{\text {st }}, 2008$ at the same temporary ponds where the egg masses of $P$. diplolister were collected.

After the eclosion, the tadpoles of $P$. diplolister were kept in plastic trays until reaching the $24-25$ stage (GOSNER 1960), when the tadpoles from different egg masses were randomly transferred to plastic boxes $(12 \times 14 \times 21 \mathrm{~cm})$ following the treatments: (1) constant water volume of $2000 \mathrm{ml}$ and constant temperature of $26^{\circ} \mathrm{C}$; (2) water volume gradually reduced from $2000 \mathrm{ml}$ to $200 \mathrm{ml}$ and constant temperature of $26^{\circ} \mathrm{C}$; (3) constant water volume of $2000 \mathrm{ml}$ and constant temperature of $30^{\circ} \mathrm{C}$, and (4) decreasing water volume as in treatment (2) and constant temperature as in treatment (3). The gradual reduction in the water level was employed to simulate the water stress - characteristic of semi-arid environments, such that 150 $\mathrm{ml}$ of water were removed every three days.

The tadpoles of $R$. granulosa were subject to the same experimental design used for $P$. diplolister, except for a difference in the temperature treatments $\left(26^{\circ} \mathrm{C}\right.$ and $\left.33^{\circ} \mathrm{C}\right)$ and in the protocol for water removal (from $2000 \mathrm{ml}$ to $150 \mathrm{ml}$ ). In the water removal treatment, $1000 \mathrm{ml}$ were removed after three days of the beginning of the experiment, and later, $200 \mathrm{ml}$ of water was removed every three days, and finally on the $14^{\text {th }}$ day of experiment, $250 \mathrm{ml}$ removed, remaining only $150 \mathrm{ml}$.

On both species, each treatment was replicated 12 times simultaneously. Each plastic box received 5 tadpoles, for a total of 240 tadpoles. Measured parameters included (1) development time in terms of the number of days until the growth of the upper limbs corresponding to the stage 42 according to GosNer (1960), (2) growth in terms of the snout-vent length (SVL). The SVL was measured using a Leika MZ6 ${ }^{\circledR}$ stereomicroscope with coupled calibrated lens.

The temperatures employed in the experiments were based on records of the temperatures obtained in permanent and temporary ponds of natural systems obtained from a 5day observation period during February 2007. The temperature of $26{ }^{\circ} \mathrm{C}$ represents the mean temperature of the permanent ponds, $30^{\circ} \mathrm{C}$ represents the mean value obtained for the daily minimum and maximum temperatures of temporary ponds, and $33^{\circ} \mathrm{C}$ represents the maximum value of the temperature in temporary ponds. The temperature in the plastic boxes was controlled using a thermostat Resun ${ }^{\circledR}$. The heating and the maintenance of the water temperature were carried by conduction, so that the 48 plastic boxes $(12 \times 14 \times 21 \mathrm{~cm})$ were distributed in 12 trays with water $(9 \times 31 \times 52 \mathrm{~cm})$. A thermostat was installed in each tray. The water temperature of the plastic boxes was monitored daily.

The photoperiod was adjusted for $12 \mathrm{~h}: 2 \mathrm{~h}$ light/dark cycle. The experiment was developed in an environmental room, with temperature of $25^{\circ} \mathrm{C}$ and artificial light. The tadpoles were fed on Nutriflakes ${ }^{\circledR}$ ration, whose composition presents nutrients from animal and plant sources. The plastic boxes were cleaned and disinfected every three days. The $\mathrm{pH}$ was followed through the Labcon Test Alcon ${ }^{\circledR}$ kit for $\mathrm{pH}$ monitoring in aquaria.

The assumptions of normality and homoscedasticity were verified through Kolmogorov-Smirnov and Levene tests, respectively (MARoco 2003). The variables dependent on development time and body size of $P$. diplolister met the assumptions and the analyses proceeded with two-way ANOVAs (QuinN \& KeOogh 2004). The analyses were performed using the software SPSS 8.0 for Windows. In the case of $R$. granulosa, three dependent variables did not meet the assumption of normality and the analyses proceeded with permutational multivariate analysis of variance (PERMANOVA - ANDERSON 2005), also with two factors. The level of significance considered was 0.05 and corrected according the method of Bonferroni (MAroco 2003), i.e. 0.025 for all analyses.

\section{RESULTS}

The mortality of the larvae of $P$. diplolister and the presence of outliers implied in the reduction of the number of replicates to seven per treatment, where each replicate represents the measure of development time and body size of four tad- 
poles, for a total of 112 analysed larvae. Likewise, the PERMANOVAs were carried with nine replicates per treatment, where every replicate represents the mean development time and the body size of three tadpoles, for a total of 108 analysed larvae.

\section{Time of metamorphosis}

The larval period of $P$. diplolister tadpoles of varied from 9 to 35 days $(\bar{x}=23, S D=3.2, n=112$, Tab. I). The time of the species metamorphosis was influenced by the temperature $(\mathrm{p}$ $<0.001$; d.f. $=1)$ and by the volume of water $(\mathrm{p}=0.025$; d.f. $=1)$, but there was no interaction between these factors $(\mathrm{p}=0.047$; d.f. = 1; Tab. II).

Table I. Development time of tadpoles of $P$. diplolister (28 tadpoles for each treatment) and $R$. granulosa (27 tadpoles for each treatment) for different treatments. Mean \pm SD (amplitude). Treatment: (1) constant volume of water $2000 \mathrm{ml}$, constant temperature of $26^{\circ} \mathrm{C}$; (2) volume of water reduced gradually from 2000 to $200 \mathrm{ml}$, constant temperature of $26^{\circ} \mathrm{C}$; (3) Constant volume and constant temperature of $30^{\circ} \mathrm{C}$ and (4) Decreasing volume and constant temperature as in the treatment (3).

\begin{tabular}{ccc}
\hline Treatment & Pleurodema dliplolister & Rhinella granulosa \\
\hline 1 & $24.8 \pm 6.4(16-34)$ & $15.2 \pm 5.3(11-38)$ \\
2 & $25.1 \pm 5.3(17-35)$ & $16.5 \pm 7.2(11-37)$ \\
3 & $18.1 \pm 60(9-32)$ & $9.4 \pm 1.6(6-13)$ \\
3 & $23.0 \pm 6.3(14-31)$ & $9.9 \pm 3.2(7-24)$ \\
\hline
\end{tabular}

The temperature induced a reduction in the time of metamorphosis regardless of the reduction in water volume. Larvae submitted to the temperature of $30^{\circ} \mathrm{C}$ reduced their development time when compared to the tadpoles kept at $26^{\circ} \mathrm{C}$. Lar- vae subject to $30^{\circ} \mathrm{C}$ and kept at a constant water volume metamorphosed earlier than tadpoles that experienced a reduction in the amount of water (Fig. 1). Moreover, the reduction of water at high temperatures seems to contribute to increase the time of metamorphosis (Fig. 1).

The larval period of $R$. granulosa varied from seven to 38 days $(\overline{\mathrm{x}}=12.7$, S.D. $=3.6, \mathrm{n}=108$, Tab. I). The development time of this species was influenced only by the temperature ( $\mathrm{p}=0.001$; d.f. $=1$; Tab. II). Tadpoles subject to $33^{\circ} \mathrm{C}$ anticipate the metamorphosis when compared to the tadpoles kept at $26^{\circ} \mathrm{C}$ (Fig. 2). Again, the reduction of development time in high temperatures was independent of the volume of water and no interaction between the two factors was detected.

\section{Body size}

The rostrum-cloacal length of the tadpoles of $P$. diplolister varied from 9.4 to $14.7 \mathrm{~mm}(\overline{\mathrm{x}}=5.8$, S.D. $=0.3, \mathrm{n}=108$, Tab. III). The body size of this species was influenced only by the change in the water level ( $p=0.002$; d.f. $=1$; Tab. IV). Larvae that experienced a reduction in water level were smaller than those subject to constant water volume (Fig. 3).

Table III. Summary values of the rostrum-cloacal length of $P$. diplolister (28 tadpoles in each treatment) and $R$. granulosa (27 tadpoles in each treatment). Mean \pm SD (amplitude). Please, read the description of the treatment in the captions of table I.

\begin{tabular}{ccc}
\hline Treatment & P. diplolister & R. granulosa \\
\hline 1 & $12.1 \pm 1.0(9.8-14.7)$ & $5.7 \pm 0.4(5.2-7.1)$ \\
2 & $11.6 \pm 0.8(9.8-12.8)$ & $5.5 \pm 0.4(4.4-6.3)$ \\
3 & $11.8 \pm 1.1(9.4-14.0)$ & $6.2 \pm 0.4(5.3-6.9)$ \\
4 & $11.2 \pm 0.9(9.6-13.3)$ & $5.8 \pm 0.5(4.8-7.4)$ \\
\hline
\end{tabular}

Table II. Summary of Two-Way ANOVA and PERMANOVA performed with the variable development time of $P$. diplolister and $R$. granulosa, respectively.

\begin{tabular}{|c|c|c|c|c|c|c|c|c|}
\hline \multirow{2}{*}{ Factors } & \multicolumn{4}{|c|}{ P. diplolister } & \multicolumn{4}{|c|}{ R. granulosa } \\
\hline & $\mathrm{DF}$ & SS & $\mathrm{F}$ & $p$ & $\mathrm{DF}$ & SS & $\mathrm{F}$ & $p$ \\
\hline Water & 1 & 46.931 & 5.712 & 0.025 & 1 & 4.6944 & 0.4665 & 0.529 \\
\hline Temperature & 1 & 136.181 & 16.574 & 0.000 & 1 & 367.3611 & 36.5079 & 0.001 \\
\hline Water vs. temperature & 1 & 36.002 & 4.382 & 0.047 & 1 & 4.6944 & 0.4665 & 0.496 \\
\hline
\end{tabular}

Table IV. Summary of Two-Way ANOVA and PERMANOVA performed with the variable body size of $P$. diplolister and $R$. granulosa respectively.

\begin{tabular}{|c|c|c|c|c|c|c|c|c|}
\hline \multirow{2}{*}{ Factors } & \multicolumn{4}{|c|}{ P. diplolister } & \multicolumn{4}{|c|}{ R. granulosa } \\
\hline & $\mathrm{DF}$ & SS & $\mathrm{F}$ & $\mathrm{p}$ & DF & SS & $\mathrm{F}$ & $\mathrm{p}$ \\
\hline Water & 1 & 2.145 & 11.936 & 0.002 & 1 & 2.2500 & 10.1250 & 0.005 \\
\hline Temperature & 1 & 0.759 & 4.223 & 0.051 & 1 & 2.2500 & 10.1250 & 0.004 \\
\hline Water vs. temperature & 1 & 8.036 & 0.004 & 0.947 & 1 & 0.0278 & 0.1250 & 0.544 \\
\hline
\end{tabular}




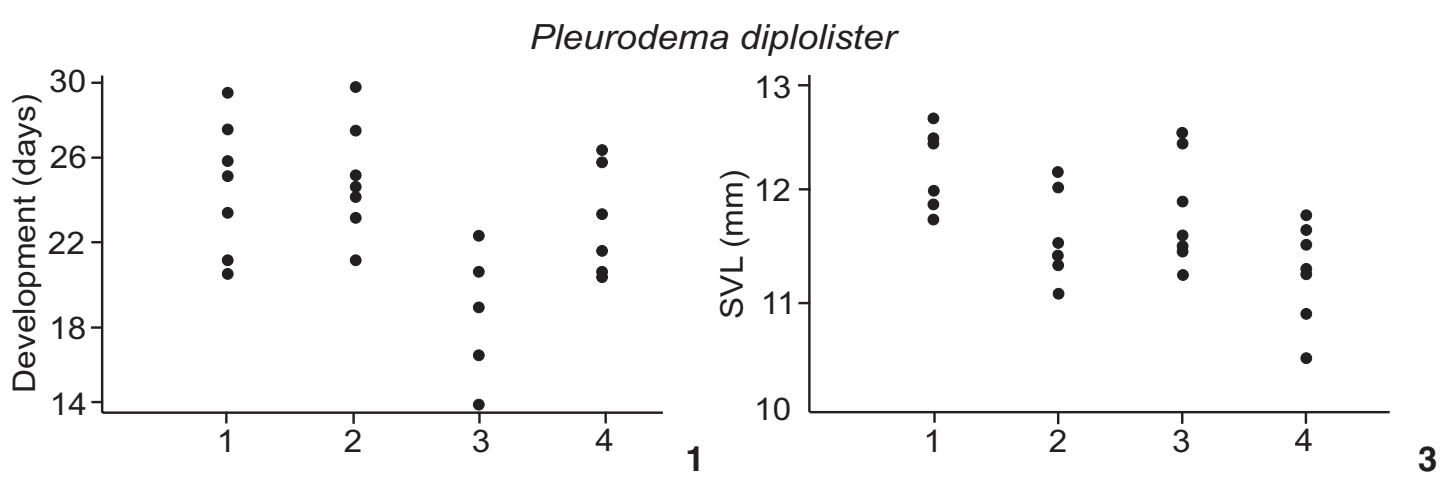

Rhinella granulosa
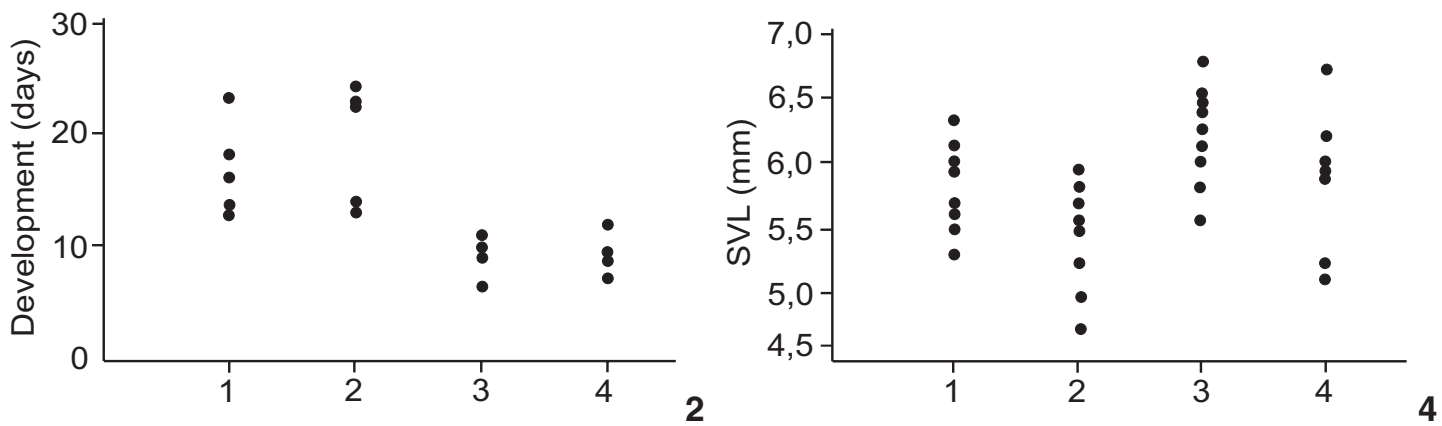

Figures 1-4. (1-2) Development time (mean number of days for the growth of the upper limbs) and (3-4) snout-vent length (SVL, in millimeters) of $P$. diplolister and $R$. granulosa tadpoles in different treatments. The tadpoles reached the developmental stage 42 , according to GOSNER (1960). See table I for a description of each treatment.

Tadpoles of R. granulosa showed a rostrum-cloacal length that varying from 4.4 to $7.4 \mathrm{~mm}(\overline{\mathrm{x}}=5.8$, S.D. $=0.3, \mathrm{n}=108$, Tab. III). The body size of this species was influenced by the water $(p=0.005$, d.f. $=1)$ and by temperature $(p=0.004$, d.f. $=1$, Tab. IV). Larvae subject to a constant volume of water grew more than larvae that experienced reduction of the water level (Fig. 4), whereas those that experienced a temperature of $33^{\circ} \mathrm{C}$ have grew more than those kept at $26^{\circ} \mathrm{C}$.

\section{DISCUSSION}

The temperature effect on the physiological processes of anuran amphibians is incontestable, mainly due to the ectothermic nature of this group (Duellman \& Trueb 1986, Ultsch et al. 1999). The relationship between temperature and development time may be physiologically explained by the influence of temperature on the endocrine system (SMith-GILl \& BERVEN 1979), specially as the factor responsible for the production of thyroxine that stimulates the development of amphibian larvae (Brown \& Frye 1969, Smith-Gill \& Berven 1979, Denver 1997). On the other hand, the reduction of the water level may accelerate the development of amphibian larvae (LaUriLa \& KuJASALO 1999, Merila et al. 2000) through the stimuli such as the nearness to the surface and the reduction of the space for locomotion, as demonstrated for Spea hammondii (DENver et al. 1998).
However, the interaction between both factors (temperature and water volume) has not influenced the development of $P$. diplolister and $R$. granulosa tadpoles, yet temperature was responsible for the reduction of the development time of the tadpoles of both species in the present study.

Contrary to other species whose tadpole development was accelerated due to a reduction in the water level, the tadpoles of $P$. dipolister developing in a reduced volume of water and exposed to $30^{\circ} \mathrm{C}$ delayed their development in approximately five days when compared to tadpoles kept in constant volume at $30^{\circ} \mathrm{C}$. This result cannot be explained by the present study.

In tadpoles of other species, the body size seems to be influenced by temperature (BROWNE \& EDWARDS 2003) or by the amount of water (CRump 1989, Newman 1989, Denver et al. 1998, Laurila \& Kujasalo 1999, Merila et al. 2000, Brady \& Griffiths 2000), but the interaction between both factors was not significant for $R$. granulosa and $P$. diplolister tadpoles . In this study, the tadpoles of both species grew less when experienced reduction of the volume of water. However, contrary to what was recorded for $P$. diplolister, the rostrum-cloacal length of the $R$. granulosa tadpoles was influenced by temperature. Tadpoles of $R$. granulosa responded to temperature of $33^{\circ} \mathrm{C}$ by growing more than those kept at $26^{\circ} \mathrm{C}$. The growth increase in response to high temperatures was recorded also for Litorea aurea. Tadpoles 
of that species were subject to 15,22 , and $28^{\circ} \mathrm{C}$ and presented increase in the rostrum-cloacal length only at $28^{\circ} \mathrm{C}$ - a fact that may be related to the optimum temperature for the development of that species (BRowne \& EDWARDS 2003). In this context, the contradictory results between both species could be explained as follows. The growth increase would require an optimum temperature, not achieved in $P$. diplolister at $30^{\circ} \mathrm{C}$. Thus, more studies about optimum temperature for tadpoles of these species would be required.

Pleurodema diplolister belongs to a family exclusive to South America and uses only temporary ponds to reproduce (CARDoso \& Arzabe 1993). On other hand, R. granulosa belongs to a cosmopolitan family, with tadpoles developing in either permanent or temporary environments (GAA 2008). Therefore, it is possible that different selective pressures that acted on each species during their evolution, still in effect in their respective environments, can lead tadpoles to respond differently to distinct environmental changes (NEWMAN 1992). This could explaining the differences found between the species in this study.

The results of this study confirm the importance of temperature for this group, since this was the factor that influenced the development time of both species of tadpoles and the growth of $R$. granulosa.

Although the effect of water reduction may be confounded with the effect of increased population density, in the present study, the density effect was considered irrelevant, given that only five tadpoles were kept in each experimental unit. In addition, the reduction of the water level did not decrease the main area of locomotion because tadpoles of both species display benthonic behavior.

\section{ACKNOWLEDGMENTS}

We are grateful to N.O. Aguiar, J.O. Santana, R.S. Sampaio, and A.S. de Santana for laboratory assistance, to Fundação de Amparo à Pesquisa do Estado da Bahia (FAPESB BOL1706/2006) and the Conselho Nacional de Desenvolvimento Científico e Tecnológico (CNPq 304507/2005-9) for a fellowship to the first and second authors respectively, to the Ibama/Sisbio for the permit to conduct the study (licence 11049-1). This study was supported by Universidade Estadual de Feira de Santana.

\section{LITERATURE CITED}

Anderson, M.J. 2005. PERMANOVA: a FORTRAN computer program for permutational multivariate analysis of variance. New Zealand, Department of Statistics, University of Auckland, Available online at: http://www.stat. auckland.ac.nz/ mja/prog/PERMANOVA_UserNotes.pdf [Accessed: 20/V/2008]

BRady, L. \& R. Griffiths. 2000. Developmental responses to pond desiccation in tadpoles of the British anuran amphibians. Journal of Zoology London 252 (1): 61-69.
Browne, R. \& D. EdWARds. 2003. The effect of temperature on the growth and development of the endangered green and golden bell frog (Litoria aurea). Journal of Thermal Biology 28 (4): 295-299.

Brown, P. \& B. Frye. 1969. Effects of prolactin and growth hormone on growth metamorphosis of tadpoles of the frog, Rana pipiens. General and comparative endocrinology 13 (1): 126-138.

Cardoso, A. \& C. Arzabe. 1993. Corte e desenvolvimento larvário de Pleurodema diplolistris (Anura: Leptodactylidae). Revista Brasileira de Biologia 53 (4): 561-570.

Crump, M. 1989. Effect of habitat drying on developmental time and size at metamorphosis in Hyla pseudopuma. Copeia 1989 (3): 794-797.

Denver, R. 1997. Proximate mechanisms of phenotypic plasticity in amphibian metamorphosis. American Zoologist 37 (2): 172-184.

Denver, R.; N. Mirhadi \& M. Phillips. 1998. Adaptive plasticity in amphibian metamorphosis: response of Scaphiopus hammondii tadpoles to habitat dessication. Ecology 79 (6): 1859-1873.

Duellman, W.E. \& L. Trueb 1986. Biology of Amphibian. New York, McGraw-Hill, 670p.

Frost, D. 2008. Amphibian species of the world. Available online at: http://www. research.Amnh.org/herpetology/ amphibian/index.php [Accessed: 27/V/2008]

GAA. 2008. Global Amphibian Assessment. Available online at: http://www.globalamphibians.org/servlet/GAA?search Name=Bufo+granulosos. [Accessed: 29/V/2008]

GosNer, K.L. 1960. A simplified table for staging anuran embryos and larvae with notes on identification. Herpetologica 16 (3): 183-190.

Laurila, A. \& J. Kujasalo. 1999. Habitat duration, predation risk and phenotypic plasticity in common frog (Rana temporaria) tadpoles. Journal of Animal Ecology 68 (6): 1123-1132.

Loman, J. 2002. Temperature, genetic and hydroperiod effects on metamorphosis of brown frogs Rana arvalis and Rana temporaria in the field. Journal of Zoology London 258 (1): 115-129.

Maroco, J. 2003. Análise estatística com utilização do SPSS. Lisboa, Edições Silabo, $2^{\text {nd }}$ ed., 162p.

Merila, J.; A. Laurila; M. Pahkala; K. Rasanen \& T. Laugen. 2000. Adaptive phenotypic plasticity in timing of metamorphosis in the common frog Rana temporaria. Écoscience 7 (1): 18-24.

Narvaes, P. \& M.T. Rodrigues. 2009. Taxonomic revision of Rhinella granulosa species group (Amphibia, Anura, Bufonidae), with a description of a new species. Arquivos de Zoologia 40 (1): $1-73$.

Newman, R. 1989. Developmental plasticity of Scaphiopus couchii tadpoles in an unpredictable environment. Ecology 70 (6): 1775-1787.

Newman, R. 1992. Adaptive plasticity in amphibian metamorphosis. BioScience 42 (9): 671-678.

Quinn, P. \& J. Keoogh. 2004. Experimental designing and data analysis for biologists. New York, University Press, 442p. 
Semlitsch, R. \& H. Wilbur. 1988. Effects of Pond Drying Time on Metamorphosis and Survival in the Salamander Ambystoma talpoideum. Copeia 1988 (4): 978-983.

Smith-GILl, S. \& K. Berven. 1979. Predicting amphibian metamorphosis. The American Naturalist 113 (4): 563-585.

Tejedo, M. \& R. Reques. 1994. Plasticity in metamorphic traits of natterjack tadpoles: the interactive effects of density and pond duration. Oikos 71 (2): 295-304.

Ultsch G.; D. Bradford \& J. Freda. 1999. Physiology: coping with the environment, p. 189-214. In: R. McDiarmid \& R. Altig (Eds). Tadpoles: the biology of anuran larvae. Chicago, University of Chicago Press, 444p.

Wilbur, H. 1990. Coping with chaos: toads in ephemeral ponds. Trends in Ecology and Evolution 5 (2): 37-39.

Wilbur, H. \& J. Collins. 1973. Ecological aspects of amphibian metamorphosis. Nonnormal distributions of competitive ability reflect selection for facultative metamorphosis. Science 182 (4119): 1305-1314.

Submitted: 27.X.2008; Accepted: 11.IX.2009.

Editorial responsibility: Luciano M. Verdade 